\title{
Hawaiian Post-Shield Basalts Through Time
}

\author{
SCOATES, JAMES S. ${ }^{1}$, HARRISON, LAUREN N. ${ }^{2}$, \\ WEIS, DOMINIQUE ${ }^{1}$ \\ ${ }^{1}$ Pacific Centre for Isotopic and Geochemical Research, \\ University of British Columbia, Vancouver, BC; \\ jscoates@eoas.ubc.ca \\ ${ }^{2}$ Nuclear and Chemical Sciences, Lawrence Livermore \\ National Lab, Livermore, CA; harrison56@1lnl.gov
}

The Hawaiian-Emperor chain is the surface expression of the Hawaiian mantle plume and records volcanic activity dating as far back as $>81 \mathrm{Ma}$. The chain is divided into the Emperor Seamounts (81-47 Ma), Northwest Hawaiian Ridge (NWHR, 47-6 Ma), and Hawaiian Islands (<6 Ma). Hawaiian volcanism evolves through four stages as a volcano traverses the Hawaiian plume: alkalic pre-shield, tholeiitic shield (80$90 \%$ volcano volume), alkalic post-shield $(\sim 1 \%)$, and silicaundersaturated rejuvenated $(<0.1 \%)$. Here, the isotopic compositions ( $\mathrm{Pb}-\mathrm{Hf}-\mathrm{Nd}-\mathrm{Sr}$ ) of post-shield basalts from 13 NWHR and young Emperor Seamount volcanoes ( 8.5-55 $\mathrm{Ma}^{1,2}$ ) are investigated to (1) bridge the $>3000 \mathrm{~km}$ gap between the Hawaiian Islands and old Emperor Seamounts, and (2) establish how the Hawaiian volcanic stage paradigm continues back in time. NWHR post-shield basalts tend to have more depleted isotopic signatures than shield-stage basalts at the same volcano, a relationship similar to that observed between shield and post-shield basalts on the Hawaiian Islands. Unlike rejuvenated basalts, which present consistent isotopic compositions through time, post-shield basalts preserve the Loa and Kea affinity identified in the shield stage. The seamounts Jingū (55 $\left.\mathrm{Ma}^{2}\right)$, Unnamed (33 $\left.\mathrm{Ma}^{1}\right)$, Academician Berg $\left(32 \mathrm{Ma}^{1}\right)$, and Townsend Cromwell $(\sim 34 \mathrm{Ma})$ have the lowest ${ }^{143} \mathrm{Nd} /{ }^{144} \mathrm{Nd}$ and ${ }^{176} \mathrm{Hf} /{ }^{177} \mathrm{Hf}$ of the NWHR. This indicates a larger proportion of a depleted component in the older NWHR volcanoes compared to the younger volcanoes, aside from Loa-trend Daikakuji (47.5 $\mathrm{Ma}^{1}$ ), which exhibits the most radiogenic $\mathrm{Pb}$ and $\mathrm{Sr}$ isotopic compositions observed from a NWHR post-shield basalt. The least radiogenic $\mathrm{Sr}$ isotope ratio is from Jingū, a young ( 55 $\mathrm{Ma}^{2}$ ) Emperor Seamount volcano, and plots between the fields defined by Hawaiian Island and post-shield basalts erupted at the oldest Emperor Seamount (Detroit, 76 Ma). These multi-isotopic trends highlight the different mantle source compositions required between the oldest Emperor Seamounts and the younger Hawaiiian basalts and support a direct compositional link between Hawaiian post-shield lavas and their respective shield stages.

[1] Jicha et al (2018) Geol. 46(11), 939-942. [2] Dalrymple \& Garcia (1980) Init. Rep. DSDP 55, 685-693. 